\title{
Adoption of reverse auctions in public e-procurement: the case of Portugal
}

\author{
Óscar Cabral \\ DCSPT \\ Universidade de Aveiro \\ Aveiro, Portugal \\ oscarcabral@ua.pt
}

\author{
Luis Ferreira \\ DEGEI/GOVCOPP \\ Universidade de Aveiro \\ Aveiro, Portugal \\ lmferreira@ua.pt
}

\author{
Gonçalo Paiva Dias \\ ESTGA/GOVCOPP \\ Universidade de Aveiro \\ Aveiro, Portugal \\ gpd@ua.pt
}

\begin{abstract}
This study focuses on the adoption and use of electronic Reverse Auctions (eRA) for public procurement in Portugal, between 2013 and 2014. With this objective, we collected and analysed 8646 contract notices of public works, supplies and services for open and restricted procedures. Conclusions were drawn regarding its distribution in terms of Contracting Authorities, their organization and etymology, contracts' objects, types of purchase, type of procedure used, prices, and supporting technology. The study demonstrates that an eRA took place in $0.7 \%$ of the procedures, consistent and in line with the results advanced by the European authorities.
\end{abstract}

Keywords-e-government; e-procurement; public procurement; reverse auction; Portugal.

\section{INTRODUCTION}

Since Directives 2004/17/EC [1] and 2004/18/EC [2] entered into force in the European Union (EU) and its subsequent adoption within Portuguese National Law in 2008 by the Code of Public Procurement (known in Portugal as "Código dos Contratos Públicos") [3], the use of electronic Reverse Auctions (eRA) for supplies, services and works of the public sector has gainedd its rightful regulations, allowing from a formal point of view - the adoption of these negotiating mechanisms in public procurement procedures conducted by European and National Contracting Authorities (CA).

\section{A. On the concept of eletronic Reverse Auctions}

In order to fully understand the analysis and outcomes of this study, it's important to first clarify the concept of the eRA as provided by the article 1(7) of the EU Directive 2004/17/EC [1]: "An 'electronic auction' is a repetitive process involving an electronic device for the presentation of new prices, revised downwards [authors note: thus taking the designation of reverse], and/or new values concerning certain elements of tenders, which occurs after an initial full evaluation of the tenders, enabling them to be ranked using automatic evaluation methods". Technology is thus vital to fulfil the requirements of this notion of eRA since it is used "an electronic device designed to allow competitors to progressively improve the attributes of the respective proposals (...)" in accordance to the article 140(1) of the aforementioned Portuguese Code of Public Procurement [3].

J. Silva [4] points out that the notion of this mechanism doesn't comprise "a specific form of tender, but only a procedural expedient provided to the contracting authority" that develops " (...) automatic and computerized processes (...) without human intervention". Therefore, the author emphasises the innovative and disruptive policy mind-set behind the mechanisms, linking eRA with a set of principles of " $(\ldots)$ modernisation, dematerialization and flexibility on contract awarding towards an electronic administration".

To summarize, the use of eRA in Portugal has then become possible (through the given Decree-Law above) both in open procedures, particularly in "Concursos Públicos" (open to competition), and in restricted procedures such as "Concursos Limitados por Prévia Qualificação" (a two-phase procedure with an open phase to competition and a restricted phase for short-listed candidates) or even in the case of restricted contracting mechanisms as Framework Agreements.

B. Adoption and use of electronic Reverse Auctions in the European Union and in Portugal

Despite the high emphasis that electronic public procurement (EPP) in general, and eRA in particular, have gained inside the European political agenda (mainly due to the pressures coming from the Lisbon Agenda, such as the market opening and transparency promotion principles and their externalities in the public sector), and notwithstanding the successive proposals of the European Ministerial egovernment Conferences (mainly the $3^{\text {rd }}$ in Manchester in November, 2005) [5], the policy impact evaluation of the adoption of these mechanisms, since 2004 (the year of the Directives), has been lacking depth.

The only relevant exercises that analysed the impact of the adoption of EPP and eRA, drawing conclusions as guidelines for further actions (and mostly in terms of metrics disregarding the effects), date back to 2010 and 2011. These studies conducted by the European Commission (EC) $[6,7]$, looked at the impact of the adoption on two levels: a macro European level and a micro Member States level. We will thus analyse these two scenarios focusing the latter in the Portuguese case.

At the European level, several policy impact analyses were conducted in order to understand the degree of achievements of the goals previously set forth, in terms of EPP and eRA. The results, such as the goal of having $50 \%$ of the total tenders being electronically conducted in 2010, would, however, be undervalued. These conclusions could be found in what came to be the "Green Paper on expanding the use of e-Procurement in the EU" [6], and also in the eRA examination made by the 
European Commission in 2011 resulted, among other metrics, that "the use of e-auctions is equally infrequent (less than $1 \%$ in terms of number and volume of contracts awarded) [7]. In the case of the latter, a plenty of other measures would be presented to regenerate the upcoming Directives in the field of public procurement.

At the second level, focusing only on the Portuguese case, the analysis of EC found out that, given the status of compulsory orientations regarding the adoption and use of EPP brought into force by the aforementioned Decree-Law, the country was, however, a case study, referring to its good practices in terms of EPP [6]. No references were made to eRA at the country's-level. On the other hand, none of the reports issued since $2010[8,9,10,11]$ by the "Instituto dos Mercados Públicos, do Imobiliário e da Construção, I.P." (former InCI, I.P. as the National Authority that monitors the EPP ecosystem in the country) references the use of eRA within EPP activities in Portugal, which results in the total inexistence of official data on the subject.

As such, we conducted this study in order to analyse the national use of eRA in the period of time between $1^{\text {st }}$ of January, 2013 and $8^{\text {th }}$ of April, 2014. Instead of examining the effects/extension of the outcomes of this mechanism's use in Portugal, we attempted to identify the use of eRA by the distribution of adopting CA, their organization and etymology, their contracts' objects and type of purchase, the type of procedures that integrated an eRA, tenders' prices and developing supporting technology, highlighting the most important findings, in terms of adoption of eRA inside the EPP activities in Portugal.

Having considered the introduction points above on the subject's relevance we will thereafter elaborate on the literature review underlining a four dimensions model for eRA analysis and interpretation (Section II). This will lead us to the methodology that we used in data collection (Section III). Subsequently we will focus and discuss the results achieved (Section IV) conducting us to the paper's conclusion (Section V).

\section{LITERATURE REVIEW}

The available literature suggests a focus upon four major dimensions regarding eRA analysis: (1) its characteristics [12, 13], (2) its appropriateness [14, 15, 16], (3) the adoption of eRA and integration into organizations' business processes $[17,18,19,20]$ and (4) the impacts/risks of the eRA $[21,22$, $23,24]$. The literature is also organized in accordance with the sector in which eRA are used: both the public sector $[21,25$, $26]$ and private sector, the first deserving a bigger highlight in our study.

From those dimensions, D. Aloini, R. Dulmin and V. Mininno had already made reference in their study [12] to the first two and to the latter points, revealing a pattern in the eRA analysis and having also found two major scopes of investigation: (1) conceptualization $[27,28]$ and (2) experimentation through empirical research $[29,30]$.

The use of eRA - specifically the use by the public sector is also receiving an increasing degree of attention, mostly due to the administrative modernization pressure that policies in this field have brought into agencies (as seen above on both European and national level).

From multi-level legal adoptions and regulations through the needed answer to a higher demand of transparency and effective resource allocation issued by market operators [29] [31], political decisions around e-government and tools like eRA are becoming more expressive. This is due to a higher public scrutiny over the performance of the public sector [21, $25,32]$, compelling the enhancement of the public interest reflection in the acquisitions conducted [33], which contributes to "an improvement in the relationship between administration, citizens and business (...)" [31].

In Portugal, besides the mentioned IMPIC's reports $[8,9$, 10, 11], A. Costa, A. Arantes, and L. Tavares have also drawn some conclusions through an empirical study [32] (composed by two surveys, the first in 2009 and the second in 2010) regarding the impact of EPP adoption by State's Direct administration, Indirect Administration agencies and Municipal $\mathrm{CA}$, bridging a primary input necessary to the evaluation of the field's state-of-the-art.

\section{Methodology}

The present analysis was conducted through a data collection of mandatory tenders' notices made by Portuguese CA in the II series, part "L", of the electronic version of the Official Portuguese journal "Diário da República" ${ }^{1}$ in the period between the $1^{\text {st }}$ of January, 2013 up to the $8^{\text {th }}$ of April, 2014. We analysed a total amount of 8,646 tender notices both of open and restricted procedures. Notices on deadline's extensions and tenders' rectifications were not considered. The data presented in the tables below was collected within the same source.

From the tenders' universe above, we have identified 61 publications that integrated an eRA through the affirmative answer in field no. 3 "Informação adicional" ("additional information") of their tenders to the question "É utilizado um Leilão Eletrónico:" ("It is used an eRA").

\section{RESUlts AND DisCUSSION}

\section{A. Distribution of electronic Reverse Auctions per} Contracting Authorities

From the conducted analysis we can conclude that the ranking of CA that made the greatest use of eRA, is led by several bodies with different Administration backgrounds and degrees of autonomy: from central government agencies, to municipalities, health entities, public institutes, state-owned companies, among others, as seen on Table 1.

TABLE I. LIST OF ISSUED ERA By CONTRACTING AUTHORITY

\begin{tabular}{|l|c|c|}
\hline \multicolumn{1}{|c|}{ Contracting Authority } & $\begin{array}{c}\text { No. of } \\
\boldsymbol{e R A}\end{array}$ & Distribution (\%) \\
\hline $\begin{array}{l}\text { Serviços Partilhados do Ministério da } \\
\text { Saúde, E. P. E. }\end{array}$ & 24 & $39,3 \%$ \\
\hline $\begin{array}{l}\text { CMPEA - Empresa de Águas do } \\
\text { Município do Porto, E.M. }\end{array}$ & 17 & $27,9 \%$ \\
\hline Município de Lisboa & 3 & $4,9 \%$ \\
\hline
\end{tabular}

\footnotetext{
${ }^{1}$ www.dre.pt
} 


\begin{tabular}{|c|c|c|}
\hline \multicolumn{1}{|c|}{ Contracting Authority } & $\begin{array}{c}\text { No. of } \\
\boldsymbol{e R A}\end{array}$ & Distribution (\%) \\
\hline $\begin{array}{l}\text { AdP - Águas de Portugal, SGPS, S. A. e } \\
\text { outros }\end{array}$ & 2 & $3,3 \%$ \\
\hline $\begin{array}{l}\text { SUCH - Serviço de Utilização Comum } \\
\text { dos Hospitais }\end{array}$ & 2 & $3,3 \%$ \\
\hline $\begin{array}{l}\text { Entidade de Serviços Partilhados da } \\
\text { Administração Pública, I. P. }\end{array}$ & 2 & $3,3 \%$ \\
\hline Other CA Total & 11 & $18 \%$ \\
\hline Ta & 61 & $100 \%$ \\
\hline
\end{tabular}

The CA that register a larger expression of use of the mechanism form a heterogeneous group, with regard to the sector of Public Administration they belong to, as well as to what their mission is.

B. Distribution of electronic Reverse Auctions per tenders' Common Procurement Vocabulary classification

On the other hand, in terms of classification of the tenders that included an eRA - given through the classification provided by the Common Procurement Vocabulary (CPV) framework - diversity and heterogeneity could also be found in terms of acquisition types and the purposes for which the tenders and eRA were developed: either tenders on services and/or supplies could be found among the sample of tenders that included an eRA (but not public works).

However, the most prominent set of eRA issued with CPV classification were on "Medical equipment, pharmaceuticals and personal care products" with 23 issued eRA, the CPV classification of "Telecommunications services" with 5 issued eRA, the CPV classification "Firefighting equipment" with 3 issued eRA and finally, in ex-aequo, the CPV classification of "Police cars", CPV classification of "Instruments for measuring flow, level and pressure of liquids and gases" and the CPV classification "Pipeline, piping, pipes, casing, tubing and related items" with 2 issued eRA each.

C. Distribution of electronic Reverse Auctions per type of procedure

Regarding the use of eRA per type of procedure, we concluded that 59 out of the 61 tenders that included an eRA were developed under the "Concurso Público" type of procedure (a purely open procedure to competition), which corresponds to $97 \%$ of the analysed notices. The other 2 eRA were used on a "Concurso Público urgente" type of procedure (which is similar to the "Concurso Público" but with some special criteria since it has an urgent nature and it's a faster type of procedure than the first) and another one of "Concurso Limitado por Prévia Qualificação" type of procedure (a twophase procedure with an open phase to competition similar to "Concurso Público" and a restricted phase for short-listed candidates).

D. Distribution of electronic Reverse Auctions per geography of Conctracting Authorities

In terms of geographic distribution of the CA that used eRA in their tenders, the data reveals a bipolarization between the metropolitan regions of Lisbon and Oporto, since 49 out of the 61 eRA (approximately $80 \%$ ) were issued by CA that are based in these locations.
E. Distribuition of electronic Reverse Auctions per price of tenders and per type of contract

In regard to the price of the tenders that integrated an eRA and in accordance to Fig. 1, it's highlighted the fact that in the contract' notices for the acquisition of services (16 contract notices) tenders' average price was 1,693,709.66€ (ranging from a tender's minimum price of $65 €$ up to a maximum registered price of $9,929,703 €)$. On the other hand, in the contract' notices corresponding to the acquisition of supplies (43 contract notices), tender's average price substantially decreased to $85,552.90 €$ (ranging from a tender's minimum price of $17,671.50 €$ up to a maximum registered price of $876,450 €$, from which we disconsider bid prices of $1 €$ or $0 €$, that are only admissible under certain circumstances). The other two contract notices - also irrelevant for the analysis were a special procedure for hiring out movable goods and the second was to award the right of space occupation.

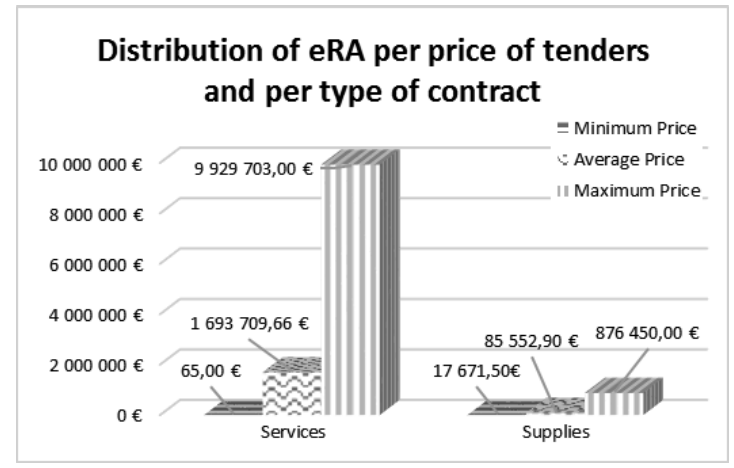

Figure 1. Distribution of eRA per price of tenders and per type of contract

F. Distribution of electronic Reverse Auctions average price per award criteria

When analysing the distribution of the average price of the procedures, from the point of view of the adopted award criteria, we found out that 50 contract notices (i.e. $82 \%$ of the contract notices that included an eRA) were published with "the lowest price" criteria. The second most used award criteria was "the most economically advantageous tender" that awarded 10 tenders (i.e. the equivalent to $16.4 \%$ of the total eRA). There was also one contract notice that had no information on the award criteria that would be used to award the contract. However, when analysing the distribution of the average tenders' price per award criteria we have identified (Fig.2) that when "the most economically advantageous tender" was used, the average contract price was substantially higher - 2,347,756.52€ - than when "the lowest price" award criteria was used, registering the latter the average price of $100,785.62 €$. 


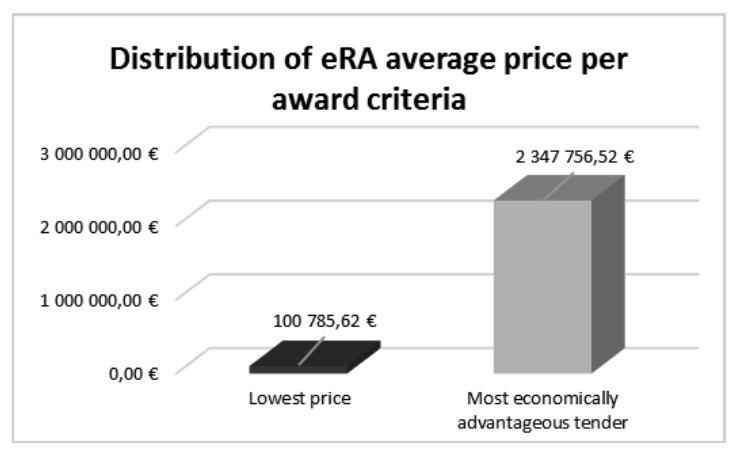

Figure 2. Distribution of eRA average price per award criteria

G. Distribution of electronic Reverse Auctions per technological platform used

In terms of the distribution of the analysed eRA per technological platform used, they were developed in accredited technologies - according to Portuguese regulations - or in a bundle of technologies. These platforms could or could not support the earlier and later stages of the electronic tender besides the eRA. They are generically speaking private-held platforms and public institutions use them to develop tenders' tasks.

Regarding the platforms where eRA took place, we've registered, in the examined period, that 19 eRA (i.e. $31,1 \%$ ) were developed through the technological combination of the "Vortal" company's platform and the e-Catalogue platform of Portuguese Health Ministry, 15 eRA were led through the "Acingov" company's platform (i.e. 24,6\%) and 18 eRA took exclusively place in "Vortal" company's platform (18\%). The other 9 eRA took place in other accredited platforms.

\section{CONCLUSIONS}

The present study reveals that the use of eRA had a residual use rate $(\mathbf{0 . 7 \%})$ in Portugal in the analysed universe, and over the period under analysis.

Bellow, we also emphasize the facts that arose from our statistical analysis over the published tenders, during the mentioned period:

- Heterogeneity was registered with regards to the Contracting Authorities that used eRA in Portugal, in terms of the Administration sector they belong to (either central government bodies, municipalities, health sector, water supply, shared services, infrastructures, etc.) and with respect to the missions they pursued;

- From the tenders that included an eRA, a plurality of contract's objects were identified for the acquisition of services and/or supplies. There were no public works contract notices in the sampled procedures that integrated an eRA;

- There was a geographical bipolarisation regarding the CA that made a greater use of eRA (from the point of where they are based). Generically speaking, the majority of CA that issued at least one eRA were based in the metropolitan areas of Lisbon or Oporto;

- There is a substantial distinction in the average price of tenders depending on the type of contracts to be awarded (either for the acquisition of services or supplies);

- $82 \%$ of the published "Concursos Públicos" that integrated an eRA made use of "the lowest price" as award criteria, even knowing that when it comes to the tenders that made use of "the most economically advantageous tender" as award criteria, the average price is significantly higher.

- $25 \%$ of the tenders that integrated an eRA were issued for the acquisition of services.

- In terms of technology (platforms) that supported the eRA development, we found out that this negotiation moments were distributed across the most relevant softwares available in the Portuguese market.

In short, the use of eRA in Portugal for the analysed period was consistent with the data presented by the European Commission in 2011, which stated that less than $1 \%$ of international open tenders in European Union made use of an eRA [7], pointing out to our calculated value of $0.7 \%$.

However, according to the "Contratação Pública em Portugal 2013" report [11] (which stands for "Public Procurement in Portugal 2013", for the year of 2013, issued by IMPIC, I.P.) the Portuguese public procurement ecosystem, in that year, awarded contracts of an approximate total amount of 4,153 million euros (which corresponds to $1,568.86$ million euros awarded through the open procedure of "Concurso Público", 174.67 million euros through the two-phase procedure explained above "Concurso Limitado por Prévia Qualificação" and, the largest share, 2,037.65 million euros through the procedure of "Ajuste Direto" (a restricted procedure with limited or no competition) and the remaining through other procedure types [11].

So, if it's true that the total volume of the Portuguese public procurement ecosystem in 2013 accounted for about $2.5 \%$ of the total volume of the Portuguese Gross Domestic Product (GPD), it is also true that in the same year, according to the same source, [11] nearly 1,05 p.p. of those $2.5 \%$ of the GPD met the legal conditions for integrating an Electronic Reverse Auction in its development (which refers to the cumulative amount of "Concursos Públicos" and "Concursos Limitados por Prévia Qualificação" where eRA could actually be used).

However, the largest mentioned share of this amount around 1.23 p.p. (of the $2.5 \%$ ) of the GDP coming from the awards through the "Ajuste Directo" procedure - could not use this negotiation mechanism under the legal impossibility that the national regulations ("Código dos Contratos Públicos" in its article 118) imposes if there is a negotiation phase to be included. Instead, a traditional negotiation should take place. Further research should be done to reflect on the possible extension of this technological negotiation mechanism to procedures where competition is restricted, given the 
aforementioned benefits and externalities, particularly in the case of "Ajuste Directo" in Portugal.

\section{REFERENCES}

[1] Directive 2004/17/EC of the European Parliament and of the Council of 31 March 2004 coordinating the procurement procedures of entities operating in the water, energy, transport and postal services sectors

[2] Directive 2004/18/EC of the European Parliament and of the Council of 31 March 2004 on the coordination of procedures for the award of public works contracts, public supply contracts and public service contracts

[3] Decree-Law no. 18/2008 of January, 29 in its revision by the DecreeLaw no. 278/2009 of October, 2 and Decree-Law no. 149/2012 of July, 12 that approves the Portuguese Code of Public Procurement (Código dos Contratos Públicos)

[4] J. Silva, "Código dos Contratos Públicos comentado e anotado", 3rd edition, Portugal, Ed. Almedina, 2010, pp. 475-476

[5] Swedish Presidency of the Council of the European Union (2009, November 18). Ministerial Declaration on e-government, Rec. of the $5^{\text {th }}$ Ministerial e-government Conf. [Online]. Available: https://ec.europa.eu/digital-agenda/sites/digital-agenda/files/ministerialdeclaration-on-egovernment-malmo.pdf

[6] European Commission. (2010, October 18). Green Paper on expanding the use of e-Procurement in the EU [Online]. Available: http://eurlex.europa.eu/LexUriServ/LexUriServ do? uri=COM:2010:0571:FIN:EN :PDF

[7] European Commission. (2011, June 27). Evaluation Report - Impact and Effectiveness of EU Public Procurement Legislation Part [Online].

Available:http://ec.europa.eu/internal market/publicprocurement/docs/m odernising_rules/er853_1_en.pdf

[8] Instituto da Construção e do Imobiliário, I.P. (InCI)/MOPTC. (2011, January 27). Contratação Pública em Portugal Relatório Sintese 2010
Avaliable: http://www.base.gov.pt/mediaRep/inci/files/base_docs/Rel_Contr_Publ 2010.pdf

[9] A. Pais, P. Ministro. (2012, December), Contratação Pública em Portugal 2011 [Online]. http://www.inci.pt/Portugues/inci/EstudosRelatoriosSectoriais/EstudosR elatrios\%20Sectoriais/RelContr_Pub 2011 final.pdf

[10] A. Pais, P. Ministro, P. (2014, March). Contratação Pública em Portugal 2012 [Online]. http://www.inci.pt/Portugues/inci/EstudosRelatoriosSectoriais/EstudosR elatrios\%20Sectoriais/Rel_Anual_Contratos_Publicos_2012.pdf

[11] C. Roriz, P. Ministro. (2015, January). Contratação Pública em Portugal 2013 [Online]. Available: http://www.base.gov.pt/mediaRep/inci/files/base docs/RelContratosPubl http://www.base.g

[12] D. Aloini, R. Dulmin, V. Mininno, "E-reverse auction design: critical variables in a B2B context", Journal of Business Process Management, vol. 18 , no. 2, pp. 219-249, 2012

[13] T. Schoenherr, V. Mabert, "Online reverse auctions: Common myths versus evolving reality", Business Horizons, 50, 2007, pp. 373-384

[14] S. Jap, S., "Online Reverse Auctions - issues, themes and prospects for the future", Journal of the Academy of Marketing Science, Vol. 30, no. 4., 2002, pp. 506-525
[15] S. Kumar, M. Maher, "Are the temptations of online reverse auctions appropriate for your business", Supply Chain Management: An International Journal, 13/4, 2008, pp. 304-316

[16] S. M. Wagner, A. P. Schwab, "Setting the stage for successful electronic reverse auctions", Journal of Purchasing \& Supply Management, 10, 2004, pp. 11-26

[17] J. L. Hartley, M. D. Lane, E. A. Duplaga, "Exploring the barriers to the adoption of e-auctions for sourcing", International Journal of Operations \& Production Management, vol. 26, no. 2, 2006, pp. 202-221

[18] J. F. Kros, S. S. Nadler, H. Chen, "The adoption and utilization of online auctions by supply chain managers", Transportation Research, Part E, 7, 2011, pp. 105-114

[19] D. Pearcy, L. Giunipero, A. Wilson, "A model of relational governance in reverse auctions", The Journal of Supply Chain Management: A Global Review of Purchasing and Supply, Winter 2007, pp.4-15

[20] S. Standing, C. Standing, P. Love, D. Gengatharen, "How organizing visions influence the adoption and use of reverse auctions", Electron Commer Res, 13, 2013, pp. 493-511

[21] S. Croom, A. Brandon-Jones, "Impact of eProcurement: Experiences from implementation in the UK public sector", Journal of Purchasing \& Supply Management, 13, 2007, pp. 294-303

[22] M. Emiliani, C. Giampietro, "Coercion and reverse auctions", Supply Chain Management: An International Journal, 12/2, 2007, pp. 75-84

[23] J. Nakabayashi, "Small business set-asides in procurement auctions - an empirical analysis", Journal of Public Economics, 100, 2013, pp. 28-44

[24] L. Smeltzer, A. Carr, "Electronic reverse auctions - Promises, risks and conditions for success", Industrial Marketing Management, 32, 2003, pp. $481-488$

[25] G. Oruezabala, J. Rico, "The impact of sustainable public procurement on supplier management”, Industrial Marketing Management, 41, 2012, pp. 573-580

[26] M. Shalev, S. Asbjornsen, "Electronic Reverse Auctions and the public sector - factors of success", Journal of Public Procurement, Volume 10, Issue 3, Fall 2010, pp. 428-452

[27] S. Kumar, C. Chang, "Reverse Auctions - how much total supply chain cost savings are there - a conceptual overview", Journal of Revenue and Pricing Management, vol. 6, 2, 2007, pp. 77-85

[28] J. Teich, H. Wallenius, J. Wallenius, O. Koppius, "Emerging Multiple issue e-auctions", European Journal of Operational Research, 159,2004, pp. 1-16

[29] T. Hawkins, M. Gravier, C. Wittmann, "Enhancing reverse auction use theory an exploratory study", Supply Chain Management: An International Journal 15/1, 2010, pp. 21-42

[30] R. Tassabehji, W.A. Taylor, R. Beach, A. Wood, "Reverse e-auctions and supplier-buyer relationships an exploratory study", International Journal of Operations \& Production Management, vol. 26, no. 2, 2006, pp.166-184

[31] E. Lopes, L. Portugal, "Estratégias de e-procurement na Administração Pública - uma revisão da literatura", Proceedings of the $1^{\text {st }}$ Iberian Conference on Information Systems and Technologies, Ofir, vol. 1, 2006 pp. 439-454

[32] A. Costa, A. Arantes, L. Tavares, "Evidence of the impacts of public eProcurement: The Portuguese experience", Journal of Purchasing and Supply Management, vol. 19, Issue 4, December 2013, pp. 238-246

[33] Rasheed in K. Vaidya, A.S.M. Sajeev, G. Callender, "Critical Factors that influence eProcurement implementation success in the public sector”, Journal Of Public Procurement, Vol. 6, Issues 1 \& 3, pp. 70-99 